\title{
馬鈴薯種薯栽培上肥料要素の多少 が柆年度の生產力に及济す影響"
}

東 海 林 繁 治

(宫城縣農事試驗場)

\section{緒言}

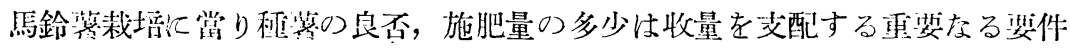

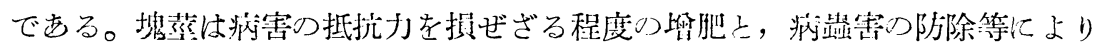

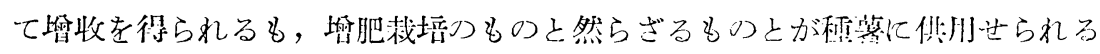

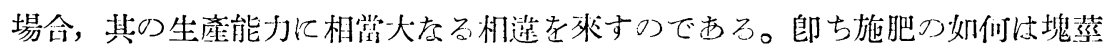

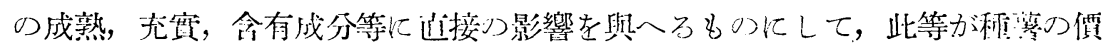

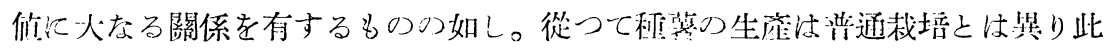

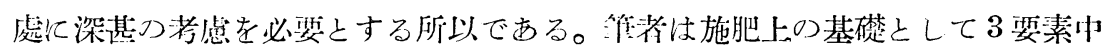

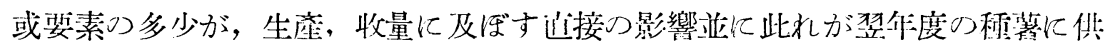

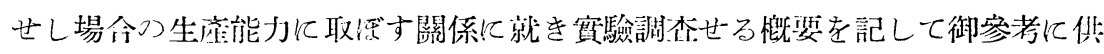
したいと思和。

\section{實 驗 方 法}

1. 装菜缺乏栽培試驗

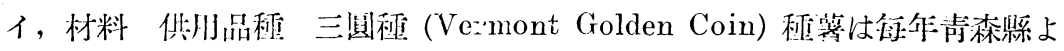
り取等せをる萎縮接少き必の老供用せり。

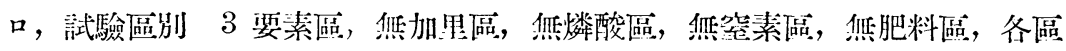

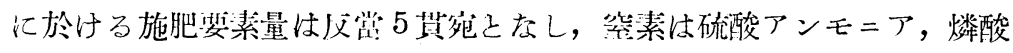
は過燐酸不灰, 加里恰硫酸加里を以て施せり。

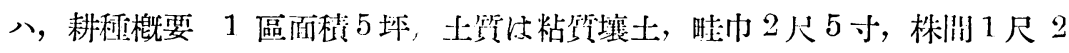
寸, 肥料は全量を 3 等分し元肥, 追肥 (2可)飞分施す。

播種期 4 月上旬，萠芽後 3 本殘し他は除去す。追肥は 5 月上旬並化下 旬に施せり，其の都度ゆ耕土寄せをなす。收檴期 8 月上旬。

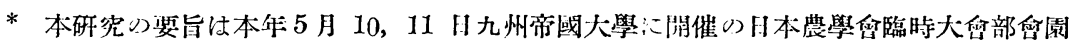
藝學既に於て發表 
2. 要素缺乏區生產塊莖》生產力に關する調查

イ，材料 要素缺乏裁培によりて得をるものを貯藏し翌春各區共當場に於け る標準耕種方法によりて栽培をなせり。

口，耕種概要 播種期 4 月上旬 晊巾 2 尺株沁 1 尺 2 寸，追肥は 5 月上旬並 亿下旬の2 包其の都度中耕土寄せをなす。收穫期は 8 月上旬。

\section{實 驗 成 績}

1. 要素缺至截培茑驗成績概要

播種後萠芽迄の日數は第 1 表 A に示せる如く各年度共施肥による影響少く

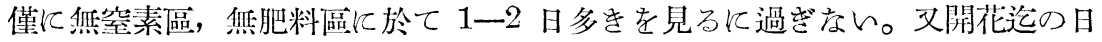
數は第 1 表 $\mathrm{B}$ に示す如く各區間に著しき差を見好も無窒素, 無肥料區に於ても 多少多き.考示し空素の不足は他の成分つ不足に比し開花を多少後らす感㐫り。

第 1 表

A 萠芽揃迄の日數

\begin{tabular}{|c|c|c|c|c|c|}
\hline 區別 & 3 装素 & 無加里 & 無燐酸 & 無咥素 & 無肥䊒 \\
\hline 1932 & 40 & 39 & 40 & 40 & 42 \\
\hline 1933 & 30 & 30 & 30 & 30 & 30 \\
\hline 1934 & 40 & 40 & 40 & 41 & 42 \\
\hline 平均 & 36.6 & 36.3 & 36.6 & 37.0 & 38.0 \\
\hline
\end{tabular}

B 開花初迄の日數

\begin{tabular}{|c|c|c|c|c|c|}
\hline 澏斺 & 3 姴素 & 無加里 & 無橉酸 & 無窒素 & 無肥料 \\
\hline 1932 & 69 & 69 & 69 & 69 & 69 \\
\hline 1933 & 56 & 57 & 55 & 57 & 57 \\
\hline 1934 & 66 & 67 & 65 & 69 & 70 \\
\hline 平均 & 63.6 & 64.3 & 63.0 & 65.0 & 65.3 \\
\hline
\end{tabular}

蓙葉の發育は第 2 表に見る如く各年度共完全區最も大にして，無燐酸區，無 加里區つ順を示し，奥䇪素，舆肥料區は最も小なり。此れを 3 ケ年の平均に見 ると 3 要素區の 2 分の 1 に過ぎない。

第 2 表

A 草丈調査 (6 日下旬)

\begin{tabular}{|c|c|c|c|c|c|}
\hline 度 & 3 㬝素 & 無加里 & fit & 無窒素 & A \\
\hline 1932 & $\begin{array}{r}\overline{\mathrm{cr}} \\
121.6\end{array}$ & $\begin{array}{r}\mathrm{cm} \\
89.1\end{array}$ & $\begin{array}{r}\mathrm{cml} \\
96.3\end{array}$ & $\begin{array}{r}\mathrm{cm} \\
65.2\end{array}$ & 51.4 \\
\hline $193 ?$ & 73.0 & 50.6 & 61.9 & 40.6 & 35. \\
\hline 1934 & 106.0 & 75.6 & 89.5 & 61.9 & 55.4 \\
\hline 平均 & 100.2 & 71.7 & 82.5 & 55.7 & 47.3 \\
\hline 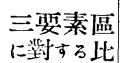 & 100.0 & 70.3 & 80.9 & 546 & 46 \\
\hline
\end{tabular}

$\mathrm{B}$ 節 數 (6 月下旬)

\begin{tabular}{|c|c|c|c|c|c|}
\hline 區別 & 3 㳅素 & 無加里! & 無燐酸 & 無寉素 & 無肥料 \\
\hline 1932 & 27.9 & 25.3 & 26.8 & 20.7 & 18.2 \\
\hline 1933 & 22.0 & 20.8 & 21.5 & 18.1 & 17.6 \\
\hline 1634 & 25.0 & 22.5 & 25.1 & 20.0 & 19.2 \\
\hline 平均 & 24.9 & 22.9 & 24.4 & 19.6 & 18.3 \\
\hline $\begin{array}{l}\text { 三要素區 } \\
\text { に對する比 }\end{array}$ & 100.0 & 91.6 & 98.0 & 78.7 & 75.5 \\
\hline
\end{tabular}


$\mathrm{C}$ 平均節間 $(6$ 月下旬)

\begin{tabular}{|c|c|c|c|c|c|}
\hline 區別 & 3 偠素 & 無加旦 & 無燐酸 & 無堂素 & 無肥料 \\
\hline & & & & & \\
\hline 1932 & 4.35 & 3.52 & 3.58 & 3.14 & 2.82 \\
\hline 1933 & 3.31 & 2.43 & 2.87 & 2.24 & 2.00 \\
\hline 1934 & 4.24 & 3.36 & 3.56 & 3.09 & 2.88 \\
\hline 平均 & 3.96 & 3.10 & 3.32 & 2.82 & 2.56 \\
\hline $\begin{array}{l}\text { 三要素區 } \\
\text { 對す吡 }\end{array}$ & 100.0 & 78.3 & 83.8 & 71.2 & 64.6 \\
\hline
\end{tabular}

3 分つ 1 亿過ぎない。
地上茞の節數並に平均節間は夫ぬ 草丈に應じて增減を示して居る（第 2 表 B.C 參(留)。

收穫期に於ける蕉葉量住第 3 表に 示艺る如く草丈と同糕 3 要素區に比 し，無燐酸無加里區の差は小なれ共 舆空素區は約 2 分つ 1 無肥料區は

第 3 表 蕉 葉 重(收穫值前)

\begin{tabular}{|c|c|c|c|c|c|c|c|c|c|c|c|c|}
\hline & \multirow{2}{*}{$\mid \begin{array}{ll}3 \text { 淛素 } \\
\text { 重 } & \text { 量 }\end{array}$} & \multicolumn{5}{|c|}{3 要素に對する比\% } & & \multirow{2}{*}{$\mid \begin{array}{ll}3 \text { 媭素 } \\
\text { 重 }\end{array}$} & \multicolumn{4}{|c|}{3 要素區に齗する比\% } \\
\hline & & 合 & 無加回 & 無燐酸 & 舞掌 & $\mid$ 無肥 & & & 步 & 無加里 & 無燐酸 & 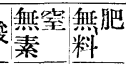 \\
\hline 1932 & 1328.5 & 100.0 & 87.2 & 106.9 & 46.6 & \begin{tabular}{l|l|}
6 & 28.2
\end{tabular} & 1935 & 474.8 & 100.0 & 78.5 & 75.7 & 42.832 .1 \\
\hline 1933 & 586.5 & 100.0 & 64.4 & 53.8 & 38.3 & 325.8 & 平均 & 796.6 & 100.0 & 79.8 & 87.8 & 43.828 .2 \\
\hline
\end{tabular}

收量調查つ洁喿は第 4 表に示岸り。

第 4 表 收 量 調 查

\begin{tabular}{|c|c|c|c|c|c|c|c|c|c|c|c|c|}
\hline & \multicolumn{2}{|r|}{ 總 } & 收 & 量（亘 & 量) & & \multicolumn{6}{|c|}{ 上 薯 (75 瓦以上) 收量 } \\
\hline & 3 要素 & \multicolumn{5}{|c|}{ 3项素區に對する比\% } & 3 埂素 & \multicolumn{5}{|c|}{3 要素區に對する比\% } \\
\hline & 重 量 & 步 & 無加里 & 無燐 & 窒素 & 無肥料 & 重 量 & & 無加里 & 與燐酸 & 無窒素 & $\begin{array}{l}\text { 無肥 } \\
\text { 料 }\end{array}$ \\
\hline 1932 & $\begin{array}{r}\mathrm{kg} \\
2873.3\end{array}$ & 100.0 & 79.1 & 92.6 & 84.9 & 92.1 & $\begin{array}{r}\mathrm{kg} \\
1597.1\end{array}$ & 100.0 & 72.9 & 165.9 & 103.9 & 39.3 \\
\hline 1933 & 2941.2 & 100.0 & 51.8 & 96.8 & 56.8 & 33.6 & 1833.8 & 100.0 & 21.2 & 67.5 & 13.3 & 2.6 \\
\hline 1634 & 2971.6 & 100.0 & 62.3 & 91.3 & 69.5 & 42.7 & 609.9 & 100.0 & 43.2 & 102.8 & 54.5 & 18.9 \\
\hline 平均 & 2928.7 & 100.0 & 64.6 & 100.1 & 74.9 & 50.2 & 1905.9 & 100.0 & 44.5 & 109.2 & 53.5 & 19.4 \\
\hline
\end{tabular}

總收量に於て無肥料區の最も少きは當然なり。3 要素中燐酸に比して加里, 空素による影響多く上荃の量を見るに於て特に明かである。而して哭肥料區， 無加里區，無空素區は何れも總收量に對する上著の割合は小なり。

第 5 表 硬度测 定 (1933) (三木式檢壁計Plunger 6mm)

\begin{tabular}{c|c|c|c|c|c|c}
\hline \hline & 3 要 素 & 無加里 & 無 燐 酸 & 無絰 素 & 無 肥 料 & 調 查 數 \\
\hline 硬度 (皌) & $66.0 \pm 0.649$ & $65.6 \pm 0.753$ & $63.2 \pm 0.622$ & $66.1 \pm 0.601$ & $70.4 \pm 0.560$ & 各 50 \\
\hline
\end{tabular}

各區に於て生產せられたる塊蒥に就き肉筫の充實度を見るが篇め硬度計を使 用し確度の测定せる結果恃第 5 表に示せる如く無肥料區最も大にして，無空素 


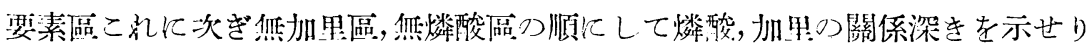

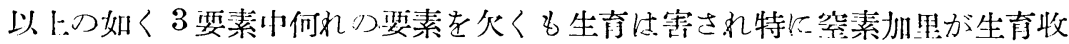

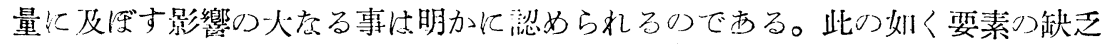

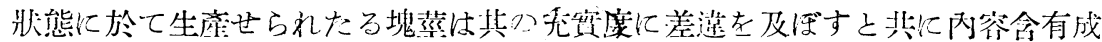

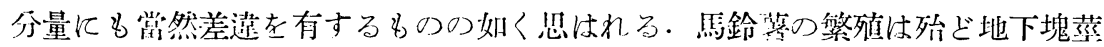

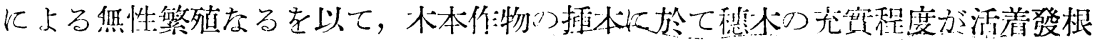

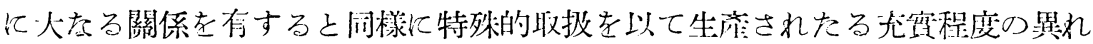

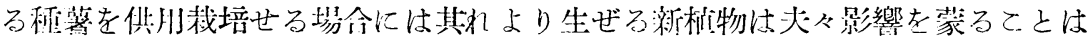

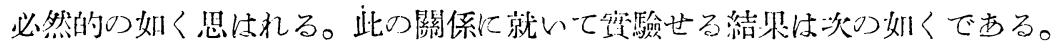

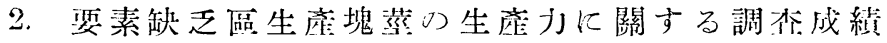

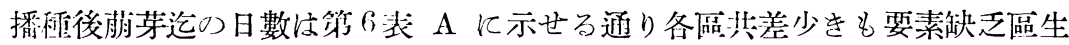
商つ怘つは 3 装素區產に比して多少多くの日數を恐して雇る。

第

A 萠苛揃迄の日数

\begin{tabular}{|c|c|c|c|c|c|}
\hline 年度 & 3 装装 & 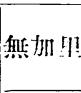 & 然嵝酸 & 與䆖素 & 舤肥料 \\
\hline 1933 & 24 & 25 & 25 & 26 & 27 \\
\hline 1934 & 34 & 43 & 36 & 40 & 41 \\
\hline 1935 & 29 & 30 & 30 & $3 \Xi$ & 33 \\
\hline 平均 & 29.0 & 32.6 & 30.3 & 32.6 & 33.6 \\
\hline
\end{tabular}

B 開花初遥の日數

\begin{tabular}{|c|c|c|c|c|c|}
\hline 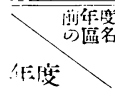 & | 3 装素 & 奥加!! & 艪燐陑 & 船学素 & 䑮肥 \\
\hline 1933 & 56 & 56 & 57 & 57 & 57 \\
\hline 1984 & 62 & 62 & 63 & 62 & 62 \\
\hline 1985 & 66 & 66 & 66 & 67 & 67 \\
\hline 平均 & 61.3 & 61.3 & fi1. 6 & 62.0 & 62.0 \\
\hline
\end{tabular}

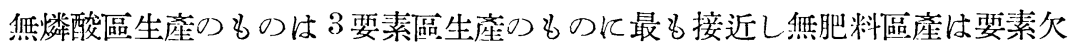
そ栽培に於けると同樣多くの日數を要して居る。開花迄の日數は各區に於て大 なる差を現はさぬも萠芽に於ける如き傾问を示せり。

第

$\mathrm{A}$ 生育調查 1935 (6月上旬)

\begin{tabular}{|c|c|c|c|}
\hline 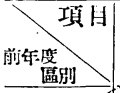 & 草 丈cm & 數 & 棓胃杏株数 \\
\hline 3 装素澳 & $26.4 \pm 0.60$ & $13.6 \pm 0.29$ & 50 \\
\hline 無加占!區 & $26.4 \pm 0.46$ & $14.3 \pm 0.28$ & 50 \\
\hline 無燐酸區 & $39.4 \pm 0.78$ & $15.9 \pm 0.26$ & 50 \\
\hline 無空素區 & $32.1 \pm 0.62$ & $13.6 \pm 0.42$ & 50 \\
\hline 舤肥料回 & $43.0 \pm 0.72$ & $15.6 \pm 0.19$ & 50 \\
\hline
\end{tabular}

表

B 無肥料區產種薯に對する备愠の比較

\begin{tabular}{|c|c|c|c|c|}
\hline \multirow{2}{*}{ 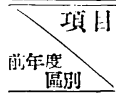 } & 草 & $D . M$ & \multirow{2}{*}{ 節 } & \multirow{2}{*}{$\frac{D . M}{P \text { E.D.M }}$} \\
\hline & 久 & P.T.I.M & & \\
\hline 3 要 & $16.60 \pm 0.94$ & 17.65 & $2.08 \pm 0.35$ & 5.83 \\
\hline 舆 加 $1 !$ & $16.60 \pm 0.86$ & 19.25 & $1.36 \pm 0.34$ & 3.97 \\
\hline 無 跣 酸 & $10.88 \pm 0.98$ & 11.02 & $2.04 \pm 0.47$ & 4.32 \\
\hline 無辤素 & $3.56 \pm 1.06$ & 3.34 & $0.26 \pm 0.33$ & 0.78 \\
\hline 與肥 料 & 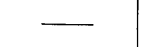 & & - & - \\
\hline
\end{tabular}




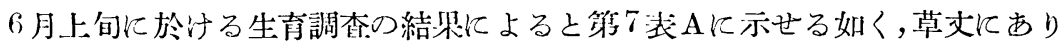

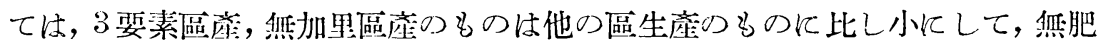
料區產のもの㵊も大なり。热肥料區產のものと他區產のものとの差は第 7 㳖

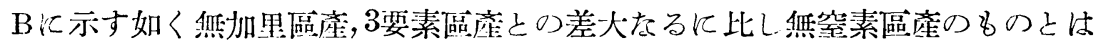
極めて小なり。節數に於ても無究素區產は哭肥料區產の者と殆ど差なきが如く 其他は们れも热肥料區產心者に比して少く草丈上同柡なる傾向を示して居る。

第

A 6 月下何に於忛る草丈

\begin{tabular}{|c|c|c|c|c|c|}
\hline 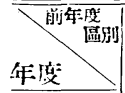 & 3 㛄素 & 舆加 4 & 奥燐酸 & 無窈秦 & 艁肥料 \\
\hline 1933 & $\begin{array}{r}c_{111} \\
29.0\end{array}$ & $\begin{array}{r}\operatorname{cin} \\
32.4\end{array}$ & $\begin{array}{r}\text { (in } \\
31.1\end{array}$ & $\begin{array}{r}\mathrm{cm} \\
40.1\end{array}$ & $\begin{array}{r}\mathrm{cin} \\
40.5\end{array}$ \\
\hline 1934 & 36.6 & 41.9 & 46.6 & 76.3 & 75.0 \\
\hline 1935 & 30.3 & 29.9 & 46.4 & 60.4 & 73.0 \\
\hline 平均 & 31.9 & 34.7 & 41.3 & 58.9 & 62.8 \\
\hline 比窈 & 100.0 & 108.8 & 129.5 & 184.6 & 196.9 \\
\hline
\end{tabular}

C 平均 節 間

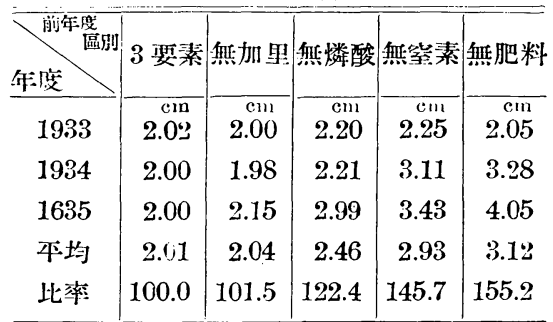

8 表

B 節 數 (6 月下旬)

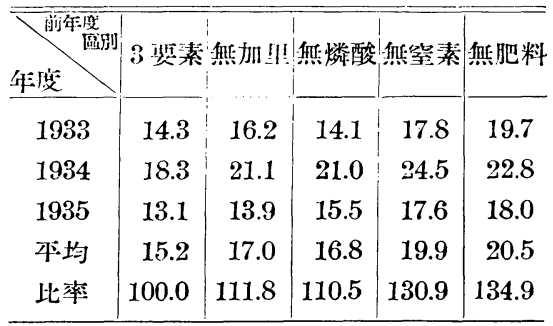

更らに 6 月下旬に調查せる成䋶は 第8表化示せり。草丈は上旬代於て 示されたる如く各年度基㶵肥料區座

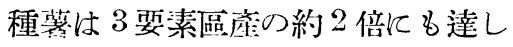

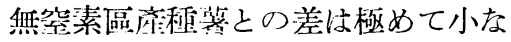

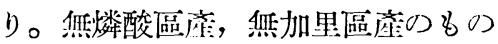
は 3 姴素區產より僅に大なるに過ぎずして前二者と大去る差を生ずる。節數並

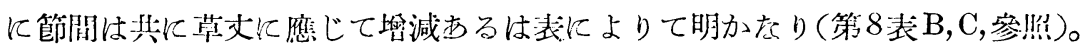

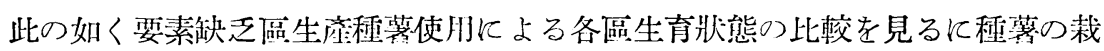
第 9 表 生育調査の階級別分類表（1935）

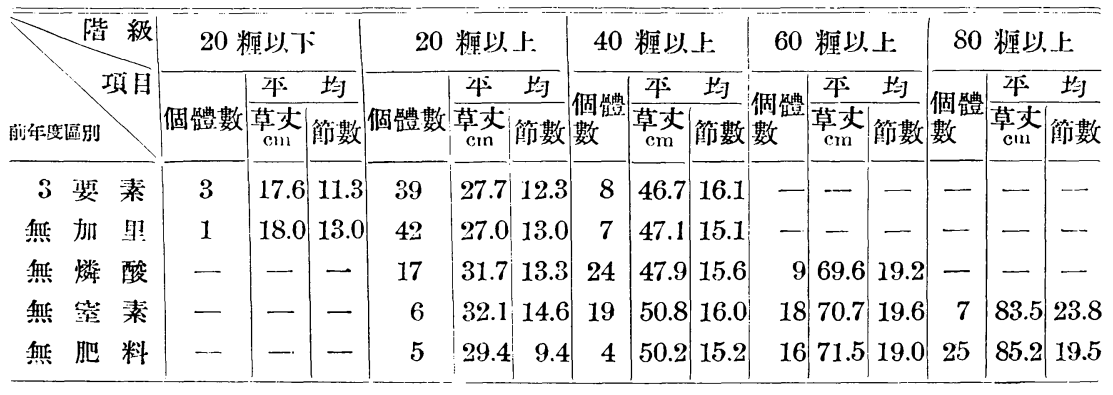


培 (要素缺乏栽培) 飞於て示されをる成䋶と反する結果を示せり。草丈测定つ 內容は要素缺乏栽培にありては，各區の测定價は個體每に接近するも，塊菣を 翌年供用栽培する時は各區共個體每に相當大圾る差を示して居る。1935 年に 調查せるものにつを階級別に分類表示すれ第 9 表に示せる如し。

此れによると草丈 40 糎以下のもの纥 3 要素區產，無加里區產，無燐酸區崖

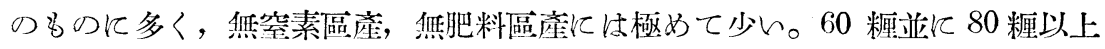

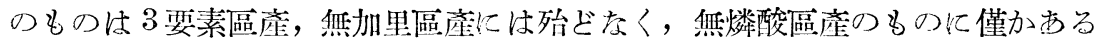

第 10 表 收穫期に於ける蕉葉重量 (1935)

\begin{tabular}{|c|c|c|c|c|c|}
\hline 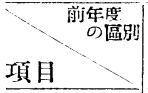 & 3 制素 & 無加里 & 舆燐酸 & 無壁素 & 無肥料 \\
\hline 重 量 瓦 & 165.8 & 169.0 & 396.2 & 471.4 & 844.6 \\
\hline 比 率 & 100.0 & 101.9 & 239.0 & 284.3 & 509.4 \\
\hline
\end{tabular}

に過ぎ老い。無肥料區產 に於ては其の大部分を占 め，無窜素區產又其の大 半を占めて居る。

收穫期に於ける蔓葉重量は第 10 表に示す通り無肥料區產のもの最も大にし

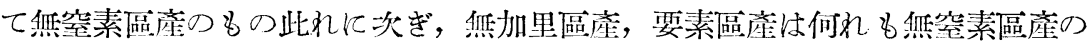

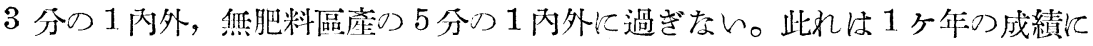

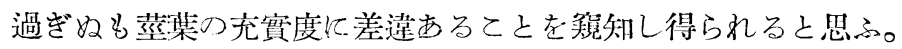

\begin{tabular}{|c|c|c|c|c|c|c|c|c|c|c|c|c|}
\hline \multirow[b]{3}{*}{$\begin{array}{l}\text { 年 } \\
\text { 度 }\end{array}$} & \multicolumn{2}{|r|}{ 總 } & \multicolumn{2}{|c|}{ 收 } & \multicolumn{2}{|l|}{ 量 } & \multicolumn{6}{|c|}{ 上薯收量（75 瓦以上） } \\
\hline & $\begin{array}{l}\text { 要素 } \\
\text { 區產 }\end{array}$ & \multicolumn{5}{|c|}{3 要素區產に啮する比\% } & $\begin{array}{l}3 \text { 要素 } \\
\text { 區 成 }\end{array}$ & \multicolumn{5}{|c|}{3 毙素區產に對する比\% } \\
\hline & 重 量 & 步 & 無加里 & 無燐酸 & 無窒素 & 無肥料 & & 步 合 & 無加昌 & 無燐酸 & 無空素 & $\begin{array}{l}\text { 無 肥 } \\
\text { 料 } \\
\end{array}$ \\
\hline 1933 & 781.2 & 100.0 & 209.0 & 174.2 & 183.3 & 224.2 & $\begin{array}{r}\mathrm{kg} \\
138.6\end{array}$ & 100.0 & 337.7 & 253.2 & 298.1 & 324.7 \\
\hline 1934 & 504.9 & 100.0 & 119.5 & 176.5 & 342.6 & 294.2 & 177.3 & 100.0 & 138.5 & 97.5 & 452.8 & 280.2 \\
\hline 1935 & 509.9 & 100.0 & 149.1 & 280.9 & 376.7 & 454.6 & 163.4 & 100.0 & 127.3 & 371.3 & 521.2 & 872.7 \\
\hline 本均 & 597.0 & 100.0 & 158.9 & 198.2 & 275.6 & 300.3 & 159.8 & 100.0 & 192.3 & 235.9 & 431.4 & 495.0 \\
\hline
\end{tabular}

收量調查の結果は第 11 表に示す通りにして年度により多少の差違共， 3 要素區產つものに比して他は何れも增收して居る。無肥料區產流最も多く， 無窒素區產此れに次ぎ共に 3 要素區產の約 3 倍化達し次んで無燐酸區產，無加 里區產つ順位を示し，生育に於ける如き傾向を示して居る。此つ關係は上薯に 於て特に明かにして無肥料區產のものは 3 要素區產つ約 5 倍，無窒素區產は約 4 倍に薘し, 無燐酸區產, 無加里區產との差も總重量に於けるより大なり。此 れは 3 要素區產の種蓄使用に比して塊莖よく肥大するによる結果である。 
以上の成績により生育收量共に種薯栽培に於て見られたる成績と相反するこ とは明かに認められるのである。

\section{考察}

馬鈴著栽培上施肥量の多少，種類，施肥の方法が收量に影響を及ぼす事の大 にして就中肥料の主要成分たる3要素の過不足が生育, 收量, 品質に及成す關 係の大劣るは今更論を俟たざる所である。要素缺乏栽培試驗代於て示されたる

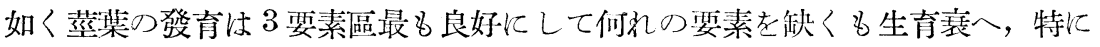
無肥料，無聜素區に於て甚しい。

要素缺乏區に於ける草丈の小なるは，微生物其他上り起る病害の篇めに非ず

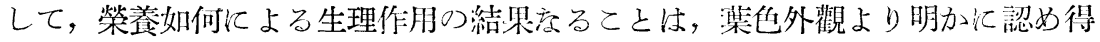
られるのである。塊莖つ收量注莖莎つ發育に密接なる關係を有する。無空素區 は 3 要素區の 2 分の 1 ，無肥料區は約 3 分の 1 程度に過ぎをい。收量の蕾加を

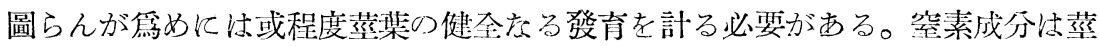
葉の發育に效果大にして收量に及ぼす影響も他の要素に比して大なる如く思は

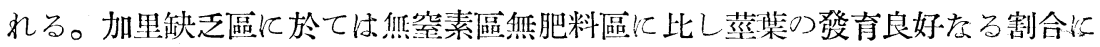
收量活少々。郎ち加里は同化作用並炕成生せられをる同化物質の移動，蓄積等 の生理作用と密接なる關係老有するに因るものの如く栽培上充分考虑す心゙き處

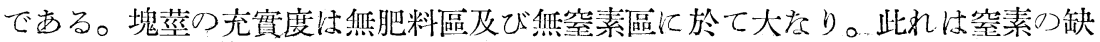
乏により荎の成熟が促進せられる外，他の區に比し，含水量，其他の成分つ上 にも多少の差違を來せる結果によるものと思はれる。或種心肥料成分を缺乏せ しめて栽培せるものより得をる塊莖を種薯として普通栽培をなす場合には，同 一をる環境を與へるも諸種の障害を來す。

萠芽，開花等は無空素區產, 無肥料區座の場合は他の何れのものにも劣り, 反 對に無肥料區產のものは何れよりも優れて居る。此の關係は要素缺乏栽培に於 けると全く反するととは兩者つ比較表（第1 圖）によりて見るも明かなり。同 一地に於的る草丈の高低は，通常施肥量つ多少，品種つ早晚，種蒡の大小等に より異るものなれ共品種，其他の管理何れも同一をるにも拘ら和種薯栽培に於 ける施肥成分の多少によりて差違を生ずる原因は他に存するものでする。發育 期間中の葉色の濃淡並に捲葉萎縮等の外徵より見て退化性萎縮病》發生による 


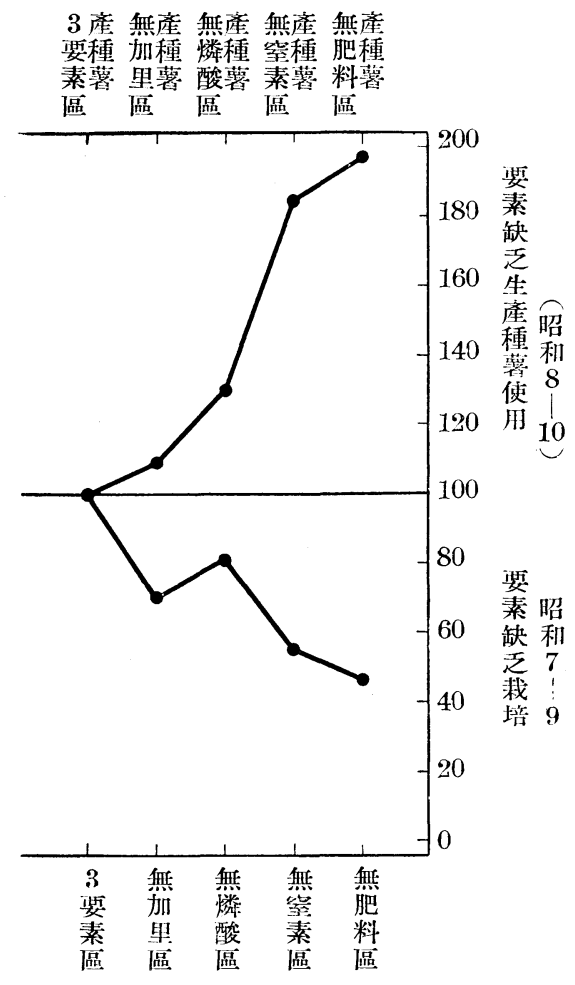

第 1 圖 草文の比較
ものと認め，1935 年度汇調查を 志せる結果は第 12 表汇示寸通り である。勿論調查個體數少く且つ 1 ヶ年の成績にして其の精確度歧 めて小灰らん女略々其等の傾向边 るととを知り得られるものと思ふ のである。

第 12 表 萎縮病株數調査法

\begin{tabular}{|c|c|c|c|c|}
\hline 項 目 & \begin{tabular}{|l} 
疤萑 \\
明
\end{tabular} & 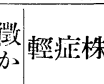 & 健余株 & 計 \\
\hline 3 惩素區 & 13 & 26 & 11 & 50 \\
\hline 無加里區 & 17 & 25 & 8 & 50 \\
\hline 無燐酸澏 & 11 & 20 & 19 & 50 \\
\hline 無空素區 & 5 & 14 & 31 & 50 \\
\hline 無肥料㕎 & 4 & 14 & 32 & 50 \\
\hline
\end{tabular}

此の表江見る如く正常なる發育 をなせるものの數は無窒素區產， 無肥料區產のものに多く其他の平 均草丈低かりし區化西りては病徽 の明かなるせのが多く見られるの

である。此れは生育調查（第 7 表，第 8 表）と照合するととにより容易に首肯 し得られるのである。

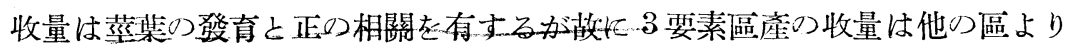

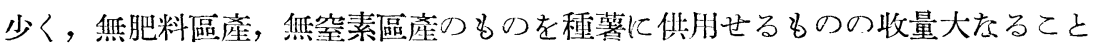
も認め得られるのである。要素缺乏栽培に於忖る收量と比較するに第 2 圖に見 る通り草丈に於けると同樣窒素つ增施によりて得をる種悉使用區は著しく減收 せる事は明かに見られるので西る。

馬鈴著栽培上 3 要素の何れを缺くも不良なる結果を受け就中窒素つ影響特に 大なり。而して該成分の多少は其の年の收量を支配する外生產塊莖学梨種著 飞供する時萎縮症弡生の多少飞密接なる關係を有するもの如し，從つて種荎生 產上此の點飞相當考虑を要するものと思考するのである。 


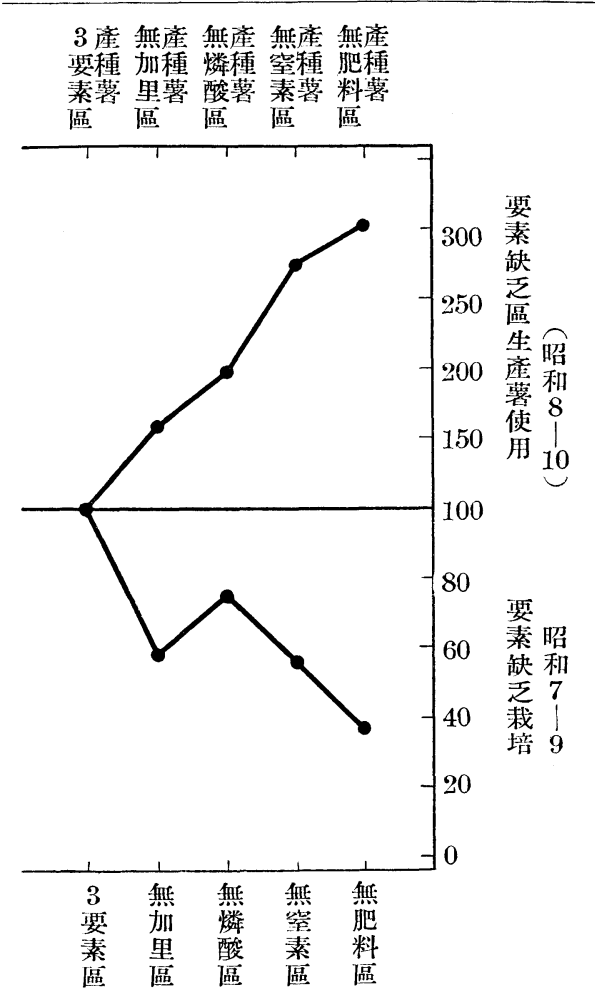

摘

要

1. 馬鈴薯の要素缺乏栽培が生 產收量に及代す影響並に此等各區

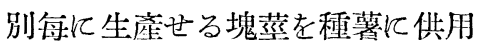
せる場合の生産並收量に及ぼす關 係に就んて調查せり。

2. 肥料 3 要素中何れを缺く 收量を減ずるも就中空素加里の影 響特沈大なり。

3. 或要素の缺乏狀態汸て生 產せられたるものを種薯となせる 場合完全肥よりも無肥料, 無窒素 狀態の下に生產されたるものは概 して良好をる結果を示せり。

第 2 圖 總收量比較表 